\title{
PENERAPAN TECHNOLOGY ACCEPTANCE MODEL (TAM) PADA E-LIBRARY BERBASIS WEB
}

\author{
Yusuf Wahyu Setiya Putra ${ }^{1)}$, Nurul Hardiyanti ${ }^{2)}$ \\ 1,2) Teknik Informatika FILKOM Universitas Selamat Sri \\ email:yusufputra21@gmail.com ${ }^{l}$, nurulhardiyanti20116043@ @mail.com ${ }^{2)}$
}

\begin{abstract}
Abstraksi
Tujuan penelitian ini adalah menganalisis penerimaan user terhadap sistem perpustakaan berbasis web atau $e$ library menggunakan variabel Kemudahan yang Dirasakan (Perceived Ease of Use), Kegunaan yang Dirasakan (Perceived Usefullness) dan Sikap Pengguna (Attitude toward Using) yang ada pada TAM (Technology Acceptance Model). Sampel yang digunakan sebanyak 38 responden. Digunakan kuesioner untuk memperoleh data yang telah diuji validitas dan reliabilitasnya dan dianalisis dengan teknik regresi linier berganda. Hasil analisis persamaan regresi ke-1 menunjukkan variabel Perceived Usefullness (X1) memiliki pengaruh signifikan terhadap variabel Attitude toward Using ( $\mathrm{Y}$ ) dengan $\mathrm{t}$ hitung sebesar 4,114 dengan signifikansi $\mathrm{p}=$ 0,000 $(<0,05)$. Variabel Perceived Ease of Use (X2) berpengaruh signifikan terhadap variabel Attitude Toward Using (Y) dengan t hitung 2,898 dengan signifikan $\mathrm{p}=0,010(<0,05)$. Hasil analisis persamaan regresi ke-2 menunjukkan bahwa variabel X1 dan X2 secara bersama-sama berpengaruh signifikan terhadap Attitude toward Using $(\mathrm{Y})$ karena nilai statistik F Hitung $=23,556$ dengan signifikansi $\mathrm{p}=0,000(<0,05)$.
\end{abstract}

\section{Kata Kunci :}

Sistem informasi, Perceived Usefulness, Attitude Toward Using, Perceived Ease of Use, TAM

\begin{abstract}
The purpose of this study was to analyze user acceptance of a web-based library system or e-library using the Perceived Ease of Use variable, Perceived Usefulness and Attitude toward Using in the TAM (Technology Acceptance). Model). The sample used was 38 respondents. Questionnaires were used to obtain data that had been tested for validity and reliability and were analyzed using multiple linear regression techniques. The results of the 1st regression equation analysis show that the variable Perceived Usefulness (XI) has a significant effect on the Attitude toward Using $(Y)$ variable with $t$ count of 4,114 with a significance of $p=0.000(<0.05)$. The variable Perceived Ease of Use (X2) has a significant effect on the Attitude Toward Using (Y) variable with $t$ count 2,898 with a significant $p=0.010(<0.05)$. The result of the second regression equation analysis shows that the variables X1 and X2 together have a significant effect on Attitude toward Using $(Y)$ because the statistical value of $F$ count $=23,556$ with a significance of $p=0.000(<0.05)$.
\end{abstract}

Keywords :

Information systems, Perceived Usefulness, Attitude Toward Using, Perceived Ease of Use, TAM.

\section{Pendahuluan}

Sistem perpustakaan berbasis web atau e-library yang baru diterapkan pada UNISS Kendal merupakan sistem yang terdigitalisasi dan berbeda dengan sistem perpustakaan sebelumnya. Oleh sebab itu, sistem yang baru perlu dilakukan analisis penerimaan apakah sistem yang baru dapat digunakan dengan baik dan bermanfaat bagi instansi tersebut.

Penerapan sistem perpustakaan yang baru ini akan menghasilkan reaksi pada pengguna sistem tersebut. Reaksi dari pengguna dapat berupa penerimaan pada sistem baru tersebut atau bahkan akan menolaknya. Davis, 1989, berpendapat bahwa kepuasan pemakai teknologi informasi merupakan indikator penting dalam menentukan keberhasilan dalam mendesain dan mengimplementasikan teknologi informasi. Menurut Davis, tingkat dimana seseorang meyakini bahwa penggunaan teknologi informasi merupakan hal yang mudah dan tidak memerlukan usaha keras dari pemakainya serta tingkat keyakinan seseorang bahwa penggunaan teknologi informasi tertentu akan meningkatkan kinerjanya. Davis juga menjelaskan bahwa tingkat penggunaan sebuah teknologi pada seseorang dapat diprediksi dari sikap perhatiannya terhadap teknologi tersebut, misalnya keinginan untuk menambah fitur pendukung dan motivasi untuk tetap menggunakannya [1].

Penelitian sebelumnya telah banyak dilakukan untuk membandingkan kedua model TAM dan UTAUT, diantaranya, perbandingan Metode TAM dan UTAUT dalam mengevaluasi penerimaan pengguna Sistem Informasi Manajemen Rumah Sakit (SIMRS) 
Rumah Sakit Jiwa Tampan Provinsi Riau, dengan hasil penelitiannya menunjukkan bahwa perbandingan metode TAM dan UTAUT didapatkan hasil Metode TAM lebih menjelaskan penerimaan pengguna SIMRS dengan konstruk kemudahan atau yang berpengaruh terhadap konstruk kegunaan sedangkan metode UTAUT menjelaskan penerimaan pengguna SIMRS dengan konstruk ekspektasi usaha berpengaruh terhadap ekspektasi kinerja [3].

Minat pengguna tehadap teknologi web check-in yang ada di bandara Kalimantan Barat. Model TAM digunakan dengan menambahkan variabel trust dan risk. Data dianalisis dengan structural equation modeling. Hasil menunjukkan bahwa model fit dengan chi 2 yang tidak signifikan dan indikator goodness of fit yang baik [4]. Penerapan aplikasi Sistem Akuntansi Persediaan yang diterapkan oleh Distrik Navigasi Kelas III Pontianak sudah dapat diterima dengan baik oleh karyawan yang menerapkanya baik secara individual maupun secara berkelompok dengan menggunakan analisis metode TAM. Pelatihanpelatihan yang diberikan selama ini ternyata tidak sia-sia dan memberikan hasil yang positif. [5].

Penelitian yang membandingkan Metode HOT FIT dan TAM dalam mengevaluasi penerapan Sistem Informasi Manajemen Kepegawaian (SIMPEG) di pengadilan tata usaha negara Pekanbaru dengan hasil kesimpulan bahwa dari perbandingan metode HOT FIT dan TAM, didapatkan hasil bahwa hasil pengolahan data metode TAM adalah metode terbaik untuk mengevaluasi penerapan SIMPEG di PTUN Pekanbaru. Metode TAM lebih menjelaskan keberhasilan penerapan SIMPEG [6]. Banyak model yang diusulkan untuk menjelaskan penerimaan teknologi informasi namun hanya TAM yang dapat dianggap sebagai model yang paling terbaik [7].

Berdasarkan penjelasan latar belakang dan beberapa penelitian diatas, metode yang dapat digunakan untuk menetukan tingkat penerimaan user terhadapat sistem perpustakaan menggunakan model TAM untuk mengetahui tingkat penerimaan sistem perpustakaan. Model TAM dipilih karena dari beberapa penelitian diatas menegaskan bahwa untuk mengukur tingkat penerimaan sistem yang paling baik adalah menggunakan model TAM. Kemudian hasil dari penelitian ini dapat digunakan untuk meningkatkan dan memperbaiki sistem informasi yang sudah ada.

\section{Metode Penelitian}

Model penerimaan sistem Technology Acceptance Model (TAM) akan digunakan dalam penelitian ini. Penelitian ini menggunakan metode kuantitatif dengan riset survei. Objek penelitian ini adalah mahasiswa yang telah menggunakan sistem perpustakaan tersebut. Instrumen penelitian menggunakan kuesioner yang berisi pertanyaan dengan menggunakan skala likert 1-5. Cara pengumpulan data dengan membagikan kuesioner kepada pengguna sistem tersebut. Analisis data dilakukan dengan bantuan software SPSS yang diolah menggunakan teknik analisis deskriptif dan teknik regresi linier berganda [8].

\subsection{Metode Pengumpulan Data}

Metode pengumpulan data dilakukan dengan cara mendapatkan data yang di olah dari jawaban kuesioner oleh responden. Proses pembuatan kuesioner merujuk pada faktor-faktor yang ada pada Technology Acceptance Model (TAM). Adapun penetuan populasi dari responden merujuk pada jumlah mahasiswa yang telah menggunakan $e$ library dengan jumlah 60 orang. Jadi jumlah populasi dari penelitian ini adalah sebesar 38 sampel/responden.

$$
n=\frac{\mathrm{N}}{\mathrm{N} \cdot d^{2}+1}(1)
$$

( $\mathrm{n}=$ Ukuran sampel)

( $\mathrm{N}=$ Ukuran populasi)

$(\mathrm{d}=$ Presisi, ditetapkan sebesar $10 \%$ dengan tingkat kepercayaan sebesar

$95 \%$ dari 60 jumlah populasi yang ada)

$$
\begin{aligned}
& =\frac{60}{\left(60 \times\left(0,1^{2}\right)+1\right)} \\
& =\frac{60}{(60 \times 0,01)+1} \\
& =37,5
\end{aligned}
$$

Dapat dilihat pada rumus pengambilan sampel di atas maka besaran sampel berdasarkan populasi dari penelitian ini adalah 38 mahasiswa. Uji validitas dilakukan untuk melihat butir-butir pertanyaan mana yang layak (representative) digunakan untuk mewakili variabel penelitian. Selain harus valid, instrument juga harus dapat diandalkan (reliable). Uji reliabilitas dimaksudkan untuk mengukur tingkat konsistensi instrumen yang digunakan. Dalam penelitian ini analisis yang digunakan adalah analisis deskriptif (univariat).

\subsection{Metode Analisis Data}

Analisis dilakukan dengan bentuk deskriptif menggunakan bantuan software SPSS untuk memperoleh hasil rata-rata serta persentase. Analisis statistik deskriptif adalah analisis dengan cara mengubah data mentah menjadi bentuk yang lebih mudah dipahami dan diinterpretasikan. Analisis ini memberi gambaran atau deskriptif suatu data. Untuk analisis pengumpulan data yaitu melalui proses pembuatan kuesioner yaitu dengan merujuk pada faktor-faktor yang ada pada Technology Acceptance Model (TAM). Langkah berikutnya adalah 
mengelola data yang sudah diperoleh menggunakan teknik analisis deskriptif dan teknik analisis regresi linier berganda.

Tipe pengukuran data yang digunakan adalah skala likert yaitu untuk mengukur sikap, pendapat dan persepsi seseorang atau sekelompok tentang kejadian. Adapun skala yang digunakan yaitu lima skala likert dengan ketentuan : Sangat Setuju(SS), Setuju (S), Netral(N), Tidak Setuju (TS), Sangat Tidak Setuju (STS) [10].

\subsection{Alur Penelitian}

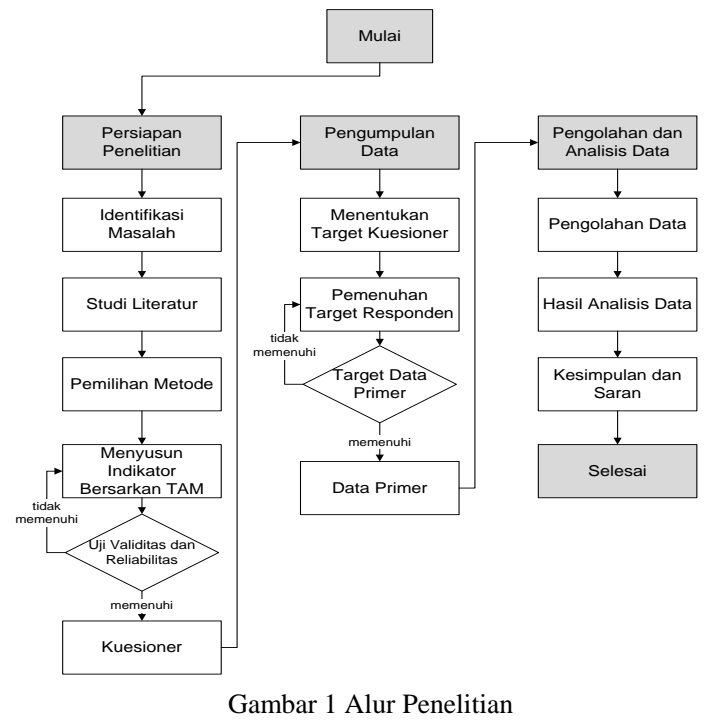

Proses yang pertama adalah melakukan perumusan masalah dari penelitian yang akan dilakukan, lalu dilakukan tinjauan pustaka dengan cara studi pustaka/jurnal yang relevan dengan penelitian yang dilakukan. Kedua adalah pengumpulan data dengan cara wawancara terhadap sumber dan melakukan penyebaran kuisioner kepada responden yang telah ditentukan. Ketiga adalah olah data dengan metode regresi linier berganda dengan langkah yang dilakukan di dalamnya adalah uji validitas dan realibilitas serta pengujian hipotesis.

\section{Hasil dan Pembahasan}

Pada bagian ini akan dijelaskan hasil dari uji instrumen penelitian, hasil uji prasyarat analisis, estimasi model regresi dan hasil pengujian hipotesis. Hasil uji instrumen penelitian terdiri atas hasil uji validitas butir instrumen dan hasil uji reliabilitas instrumen, hasil uji prasyarat analisis meliputi hasil uji normalitas residu, hasil uji heteroskedastisitas. Hasil estimasi model regresi melaporkan hasil analisis dua model persamaan regresi yang diajukan. Hasil pengujian hipotesis melaporkan hasil pengujian hipotesis yang diajukan.

\subsection{Hasil Uji Validitas Butir}

Uji validitas digunakan untuk mengetahui seberapa tepat suatu alat ukur mampu melakukan fungsinya.
Alat ukur yang dapat digunakan dalam pengujian suatu kuesioner adalah angka hasil korelasi antara skor pernyataan (skor butir) dan skor keseluruhan (skor total) pernyataan responden terhadap informasi dalam kuesioner [11]. Instrumen terlebih dahulu dinilai oleh ahli di bidangnya (expert judgment) untuk mengetahui validitas internal dari instrumen yang bersangkutan, yaitu apakah instrumen yang akan digunakan telah betul-betul mencakup konstruk dan aspek dari variabel yang bersangkutan. Lalu instrumen itu diperiksa validitas eksternalnya dengan melakukan uji coba setidaknya dengan 30 responden.

Pengujian validitas eksternal menggunakan angka (r) hasil korelasi Pearson yang dikenal dengan rumus korelasi Product Moment [12]. Dalam estimasi validitas pada umumnya tidak dapat dituntut suatu koefisien yang tinggi sekali. Koefisien validitas yang tidak begitu tinggi berada di sekitar angka 0,50 akan dapat diterima dan dianggap memuaskan. Namun apabila koefisien validitas itu kurang dari pada 0,30 biasanya dianggap tidak memuaskan [12].

Dalam penelitian ini, ada tiga instrumen yang akan divalidasi sebelum digunakan untuk mengumpulkan data di lapangan yaitu instrumen Attitude toward Using (AT, sebagai Y), Perceived Usefulness (PU, sebagai X1), dan Perceived Ease of Use (PE, sebagai X2). Perhitungan validitas instrumen yang berupa angket dengan pendekatan internal konsistensi menggunakan bantuan program SPSS. Berdasarkan hasil perhitungan apabila nilai corrected item-total correlation tersebut $\geq 0,30$ maka butir pernyataan dalam angket dinyatakan valid atau sahih [12]. Hasil uji instrumen dengan metode corrected item-total correlation adalah sebagai berikut.

a. Instrumen Attitude toward Using

Variabel Attitude toward Using diukur dengan menggunakan instrumen yang terdiri atas 6 butir pertanyaan. Berikut hasil validitas butir pada Tabel 1 .

TABEL 1 HASIL UJI VALIDITAS BUTIR INSTRUMEN ATTITUDE TOWARD USING

\begin{tabular}{clll}
\hline Butir & $\begin{array}{c}\text { Korelasi Butir- } \\
\text { Total }\end{array}$ & $\begin{array}{c}\text { Syarat } \\
\text { Minimal }\end{array}$ & Keterangan \\
\hline AT1 & 0,400 & 0,300 & Valid \\
AT2 & 0,310 & 0,300 & Valid \\
AT3 & 0,398 & 0,300 & Valid \\
AT4 & 0,450 & 0,300 & Valid \\
AT5 & 0,440 & 0,300 & Valid \\
AT6 & 0,550 & 0,300 & Valid \\
\hline
\end{tabular}

Tabel 1 menunjukkan koefisien korelasi yang berkisar dari 0,310 (butir AT2) sampai dengan 0,550 (AT6). Karena koefisien korelasi item-total lebih 
besar dari 0,300 maka dapat di ambil kesimpulan bahwa semua item adalah valid (sahih).

b. Instrumen Perceived Usefulness

Variabel Perceived Usefulness diukur dengan instrumen yang terdiri atas 6 item pernyataan yaitu PU1 sampai dengan PU6. Berikut hasil validitas butir pada Tabel 2 .

\begin{tabular}{lccl}
\multicolumn{4}{c}{ TABEL 2 HASIL UJI VALIDITAS BUTIR INSTRUMEN } \\
PERCEICED USEFULNESS \\
\hline Butir & $\begin{array}{c}\text { Korelasi Butir- } \\
\text { Total }\end{array}$ & $\begin{array}{c}\text { Syarat } \\
\text { Minimal }\end{array}$ & Keterangan \\
& 0,390 & 0,300 & Valid \\
\hline PU1 & 0,380 & 0,300 & Valid \\
PU2 & 0,410 & 0,300 & Valid \\
PU3 & 0,551 & 0,300 & Valid \\
PU4 & 0,520 & 0,300 & Valid \\
PU5 & 0,588 & 0,300 & Valid \\
PU6 & &
\end{tabular}

Tabel 2 menunjukkan koefisien korelasi yang berkisar dari 0,380 (butir PU2) sampai dengan 0,588 (PU6). Karena koefisien korelasi item-total lebih besar dari 0,300 maka dapat disimpulkan bahwa semua item instrumen perceived usefulnes adalah valid (sahih).

c. Instrumen Perceived Ease of Use

Variabel Perceived Ease of Use diukur dengan menggunakan instrumen yang terdiri atas 6 butir (item) pernyataan. Berikut hasil validitas butir pada Tabel 3 .

\begin{tabular}{|c|c|c|c|}
\hline Butir & $\begin{array}{l}\text { Korelasi Butir- } \\
\text { Total }\end{array}$ & $\begin{array}{l}\text { Syarat } \\
\text { Minimal }\end{array}$ & Keterangan \\
\hline PE1 & 0,315 & 0,300 & Valid \\
\hline PE2 & 0,514 & 0,300 & Valid \\
\hline PE3 & 0,390 & 0,300 & Valid \\
\hline PE4 & 0,540 & 0,300 & Valid \\
\hline PE5 & 0,610 & 0,300 & Valid \\
\hline PE6 & 0,641 & 0,300 & Valid \\
\hline
\end{tabular}

Tabel 3 menunjukkan koefisien korelasi item-total yang berkisar dari 0,315 (PE1) sampai dengan 0,641 (PE6). Karena koefisien korelasi item-total lebih besar dari 0,300 maka dapat disimpulkan bahwa semua item instrumen perceived ease of use adalah valid (sahih).

\subsection{Hasil Uji Reliabilitas Instrumen}

Pengujian reliabilitas instrumen digunakan untuk mengetahui konsistensi atau keteraturan hasil pengukuran suatu instrumen apabila instrumen tersebut digunakan lagi sebagai alat ukur suatu objek atau responden [11]. Salah satu metode pengujian reliabilitas adalah dengan menggunakan metode Alpha-Cronbach [12]:

Perhitungan reliabilitas instrumen dapat dilakukan dengan menggunakan formula Alpha Cronbach. Suatu instrumen dikatakan reliabel (andal) bila memiliki koefisien Alpha Cronbach $\geq 0,70$. Hasil uji reliabilitas dengan menggunakan metode Alpha Cronbach disajikan dalam Tabel 4 berikut.

TABEL 4 RANGKUMAN HASIL UJI RELIABILITAS INSTRUMEN

\begin{tabular}{lccl}
\hline \multicolumn{1}{c}{$\begin{array}{c}\text { Instrume } \\
\mathrm{n}\end{array}$} & $\begin{array}{c}\text { Alpha } \\
\text { Cronbach }\end{array}$ & $\begin{array}{c}\text { Syarat } \\
\text { Minimal }\end{array}$ & Keterangan \\
\hline $\begin{array}{l}\text { Perceived } \\
\text { Usefulness }\end{array}$ & 0,810 & 0,70 & Reliabel \\
$\begin{array}{l}\text { Perceived } \\
\text { Ease of Use }\end{array}$ & 0,790 & 0,70 & Reliabel \\
$\begin{array}{l}\text { Attitude } \\
\text { toward Using }\end{array}$ & 0,775 & 0,70 & Reliabel \\
\hline
\end{tabular}

Tabel 4 menunjukkan ketiga instrumen penelitian memiliki tingkat reliabilitas yang tinggi dan memenuhi syarat untuk digunakan mendapatkan data penelitian di lapangan. Ketiga instrumen tersebut memiliki koefisien Alpha Cronbach > 0,70.

\subsection{Hasil Analisis Deskriptif}

Analisis deskriptif digunakan untuk menggambarkan masing-masing variabel yang diteliti, yaitu Perceived Usefulness, Perceived Ease of Use dan Attitude toward Using. Analisis deskriptif pada penelitian ini mencakup penyajian mean (nilai rerata) dan juga kategorisasi data ke dalam kategori sangat rendah, rendah, sedang, tinggi, dan sangat tinggi untuk tiap variabel.

Untuk mendeskripsikan variabel penelitian, nilai rata-rata masing-masing responden pada masingmasing variabel dikelompokkan dalam 5 kelas. Cara mengetahui kecenderungan responden maka dibuat pengelompokan berdasarkan norma yang disusun sesuai dengan tingkat diferensiasi yang dikehendaki dan ditetapkan batasannya berdasarkan rentang skor minimum-maksimum teoritiknya.

Norma kategorisasi atau klasifikasi yang digunakan adalah [13] :

\begin{tabular}{llll}
\multicolumn{3}{c}{ TABEL 5 NORMA KATEGORISASI } \\
\hline \multirow{2}{*}{ Keterangan } & $\begin{array}{c}\text { Mean } \\
\text { Teoritik }\end{array}$ & Persamaan & $\begin{array}{l}\text { Standar } \\
\text { Deviasi }\end{array}$ \\
\hline Sangat rendah & $\mathrm{Mt}-1,5$ & $\geq \mathrm{X}$ & \\
Rendah & $\mathrm{SDt}$ & $\geq \mathrm{X}>$ & $\mathrm{Mt}-1,5$ \\
Sedang & $\mathrm{Mt}-0,5$ & $\geq \mathrm{X}>$ & $\mathrm{SDt}$ \\
Tinggi & $\mathrm{SDt}$ & $\geq \mathrm{X}>$ & $\mathrm{Mt}-0,5$ \\
Sangat tinggi & $\mathrm{Mt}+0,5$ & $\mathrm{X}>$ & $\mathrm{SDt}$ \\
& $\mathrm{SDt}$ & & $\mathrm{Mt}+0,5$ \\
& $\mathrm{Mt}+1,5$ & & $\mathrm{SDt}$ \\
& $\mathrm{SDt}$ & & $\mathrm{Mt}+1,5$ \\
& & $\mathrm{SDt}$ \\
\hline
\end{tabular}

Mt adalah Mean atau rata-rata teoritik, diperoleh dari penjumlah skor maksimum teoritik dan skor minimum teoritik, lalu dibagi dua atau $\mathrm{Mt}=($ Skor 
Maksimum + Skor Minimum)/2. Sedangkan SDt adalah standar deviasi teoritik yang diperoleh dari skor maksimum teoritik dikurangi skor minimum teoritik dan dibagi enam atau SDt $=$ (Skor Maksimum - Skor Minimum) /6 [13].

Instrumen keempat variabel dalam penelitian ini diukur dengan skala 5 poin yang memiliki rentang pilihan jawaban 1 hingga 5 , jadi skor tertinggi atau maksimum $=5$ dan skor terendah atau minimum $=$ 1. Mean teoritik (Mt) diperoleh sebesar $(5+1) / 2=3$ dan standar deviasi teoritik (SDt) sebesar $1 / 6 \times(5-$ $1)=0,67$. Berdasarkan mean teoritk dan standar devasi teoritik ini, maka dapat ditentukan klasifikasi dengan 5 kategori berdasarkan norma sebagai berikut :

TABEL 6 KLASIFIKASI BERDASARKAN NORMA

\begin{tabular}{llll}
\multicolumn{3}{c}{ KATEGORISASI } \\
\hline \multicolumn{1}{c}{ Keterangan } & $\begin{array}{c}\text { Mean } \\
\text { Teoritik }\end{array}$ & \multicolumn{1}{c}{ Persamaan } & $\begin{array}{l}\text { Standar } \\
\text { Deviasi }\end{array}$ \\
\hline Sangat rendah & $3-(1,5 \mathrm{x}$ & $\geq \mathrm{X}$ & \\
Rendah & $0,67)$ & $\geq \mathrm{X}>$ & $3-(1,5 \mathrm{x}$ \\
Sedang & $3-(0,5 \mathrm{x}$ & $\geq \mathrm{X}>$ & $0,67)$ \\
Tinggi & $0,67)$ & $\geq \mathrm{X}>$ & $3-(0,5 \mathrm{x}$ \\
Sangat tinggi & $3+(0,5 \mathrm{x}$ & $\mathrm{X}>$ & $0,67)$ \\
& $0,67)$ & & $3+(0,5 \mathrm{x}$ \\
& $3+(1,5 \mathrm{x}$ & & $0,67)$ \\
& $0,67)$ & & $3+(1,5 \mathrm{x}$ \\
& & & $0,67)$ \\
\hline
\end{tabular}

TABEL 7 KLASIFIKASI NILAI INSTRUMEN

\begin{tabular}{llll}
\hline \multicolumn{1}{c}{ Keterangan } & $\begin{array}{c}\text { Mean } \\
\text { Teoritik }\end{array}$ & Persamaan & $\begin{array}{r}\text { Standar } \\
\text { Deviasi }\end{array}$ \\
\hline Sangat rendah & 2,00 & $\geq \mathrm{X}$ & \\
Rendah & 2,67 & $\geq \mathrm{X}>$ & 2,00 \\
Sedang & 3,33 & $\geq \mathrm{X}>$ & 2,67 \\
Tinggi & 4,00 & $\geq \mathrm{X}>$ & 3,33 \\
Sangat tinggi & & $\mathrm{X}>$ & 4,00 \\
\hline
\end{tabular}

Berdasarkan klasifikasi di atas, dapat dilakukan proses pengelompokan data variabel penelitian dan mean empirik hasil pengukuran di lapangan dan menghitung banyak responden yang termasuk dalam tiap kelompok yang telah ditetapkan.

\section{a. Prceived Usefulness}

Mean dari variabel perceived usefulness sebesar 3,81 yang masuk ke dalam kategori "tinggi", dengan simpangan baku sebesar 0,515. Dengan menggunakan kaidah kategori dari Azwar [13] diperoleh kategori pada Tabel 8.

TABEL 8 KATEGORISASI VARIABEL PERCEIVED USEFULNESS

\begin{tabular}{lllll}
\hline & Frequency & Percent & $\begin{array}{c}\text { Percent } \\
\text { Valid }\end{array}$ & $\begin{array}{c}\text { Comulative } \\
\text { Percent }\end{array}$ \\
\hline Sedang & 7 & 18.0 & 18.0 & 10.0 \\
Tinggi & 19 & 50.0 & 50.0 & 60.0 \\
Sangat & 12 & 32.0 & 32.0 & 100.0 \\
Tinggi & 38 & 100.0 & 100.0 & \\
Total & & & & \\
\hline
\end{tabular}

Tabel 8 menunjukkan bahwa 19 (50\%) responden memberikan penilaian tinggi terhadap kegunaan yang dirasakan (perceived usefulness), disusul 12 (32\%) memberikan penilaian "sangat tinggi" terhadap kegunaan yang dirasakan.

\section{b. Perceived Ease of Use}

Mean dari variabel perceived ease of use sebesar 3,65 yang masuk ke dalam kategori "sangat tinggi", dengan simpangan baku sebesar 0,440. Dengan menggunakan kaidah kategori dari Azwar [13] diperoleh kategori pada Tabel 9.

TABEL 9 KATEGORISASI VARIABEL PERCEIVED EASE OF USE

\begin{tabular}{lllll}
\hline & Frequency & Percent & $\begin{array}{c}\text { Percent } \\
\text { Valid }\end{array}$ & $\begin{array}{c}\text { Comulative } \\
\text { Percent }\end{array}$ \\
\hline Sedang & 8 & 21.4 & 21.4 & 10.0 \\
Tinggi & 15 & 39.3 & 39.3 & 60.0 \\
Sangat & 15 & 39.3 & 39.3 & 100.0 \\
Tinggi & 38 & 100.0 & 100.0 & \\
Total & & & & \\
\hline
\end{tabular}

Tabel 9. menunjukkan bahwa 15 (39,3\%) responden memberikan penilaian tinggi terhadap kemudahan yang dirasakan (perceived ease of use), dan 15 $(39,3 \%)$ memberikan penilaian "sangat tinggi" terhadap kemudahan yang dirasakan.

\section{c. Attitude toward Using}

Mean dari variabel attitude toward using sebesar 3,60 yang masuk ke dalam kategori "tinggi”, dengan simpangan baku sebesar 0,575. Dengan menggunakan kaidah kategori dari Azwar [13] diperoleh kategori pada Tabel 10.

TABEL 10 KATEGORISASI VARIABEL ATTITUDE TOWARD USING

\begin{tabular}{lllll}
\hline & Frequency & Percent & $\begin{array}{c}\text { Percent } \\
\text { Valid }\end{array}$ & $\begin{array}{c}\text { Comulative } \\
\text { Percent }\end{array}$ \\
\hline Sedang & 6 & 12.4 & 12.4 & 12.2 \\
Tinggi & 20 & 54.9 & 54.9 & 87.6 \\
Sangat & 12 & 32.7 & 32.7 & 100.0 \\
Tinggi & 38 & 100.0 & 100.0 & \\
Total & & & & \\
\hline
\end{tabular}

Tabel 10 menunjukkan bahwa $20 \quad(54,9 \%)$ responden memberikan penilaian tinggi terhadap attutide toward using, disusul $12 \quad(32,7 \%)$ memberikan penilaian "sangat tinggi" terhadap attitude toward using.

\subsection{Hasil Uji Prasyarat Analisis}

Uji prasyarat analisis digunakan untuk mengetahui dan menguji kelayakan dari analisis regresi pada penelitian ini, yang meliputi uji normalitas residu, uji multikolinieritas dan uji heteroskedastisitas.

a. Hasil Uji Normalitas Residu

Imam Ghozali [14] menyebutkan bahwa uji normalitas bertujuan untuk menguji apakah dalam model regresi, variabel penganggu atau residual 
memiliki distribusi normal. Jika residu memiliki distribusi normal, model regresi akan mampu memberikan prediksi yang lebih akurat. Pada penelitian ini, uji normalitas residu dilakukan dengan menggunakan uji statistik nonparametrik Kolmogrov-Smirnov (K-S) untuk menguji normalitas residualnya. Dasar pengambilan keputusan uji statistik dengan Kolmogorov-Smirnov Z (1-Sample $K$-S) adalah [14]:

1) Jika nilai Asymp. Sig. (2-tailed) kurang dari 0,05 , maka $\mathrm{H}_{0}$ ditolak. Hal ini berarti data residual terdistribusi tidak normal.

2) Jika nilai Asymp. Sig. (2-tailed) lebih dari 0,05, maka $\mathrm{H}_{0}$ diterima. Hal ini berarti data residual terdistribusi normal.

Tabel 11 berikut merupakan hasil dari pengujian normalitas dengan uji KolmogorovSmirnov Z (1-Sample $K$-S) yang menyajikan nilai Z Kolmogorov-Smirnov dan nilai signifikansi p.

\section{TABEL 11 HASIL PENGUJIAN NORMALITAS RESIDU}

\begin{tabular}{lll} 
& & \multicolumn{1}{c}{$\begin{array}{c}\text { Unstandarized } \\
\text { Residual }\end{array}$} \\
\hline $\mathrm{N}$ & & 38 \\
Normal Parameters & Mean & .000000 \\
& Std. Deviation & .2889556 \\
Most Extreme & Absolute & .118 \\
Differences & Positive & .088 \\
& Negative & -.118 \\
Kolmogorov-Smirnov Z & & 1.185 \\
Asymp. Sig. (2-tailed) & & .188 \\
\hline
\end{tabular}

Tabel 11 di atas menunjukkan nilai dari Asymp. Sig. (2-tailed) sebesar 0,188 dan nilai signifikansi itu lebih besar dari tingkat signifikan 0,05. Dengan demikian $\mathrm{H}_{0}$ diterima, yang artinya data residu memiliki distribusi normal.

\section{b. Hasil Uji Multikolinieritas}

Imam Ghozali [14] menyebutkan bahwa uji multikolonieritas bertujuan untuk menguji apakah dalam model regresi ditemukan adanya korelasi yang terlalu tinggi antar variabel bebas (independen). Model regresi yang baik seharusnya tidak terjadi korelasi yang terlalu tinggi $(>0,9)$ di antara variabel independen. Untuk mendeteksi ada tidaknya multikolonieritas, dapat dilihat dari nilai tolerance dan lawannya variance inflation factor (VIF). Kedua ukuran ini menunjukkan setiap variabel independen manakah yang dijelaskan oleh variabel independen lainnya. Tolerance mengukur variabilitas variabel independen yang terpilih yang tidak dijelaskan oleh variabel independen lainnya. Jadi nilai tolerance yang rendah sama dengan nilai VIF tinggi (karena VIF= $1 /$ Tolerance). Nilai cutoff yang umum dipakai untuk menunjukkan adanya multikolonieritas adalah nilai tolerance $>0.10$ atau sama dengan nilai VIF $<10$ [14]. Hasil uji multikolinieritas dengan menggunakan nilai VIF dan Tolerance ditampilkan pada Tabel 12 berikut.

\section{TABEL 12 HASIL UJI MULTIKOLINIERITAS}

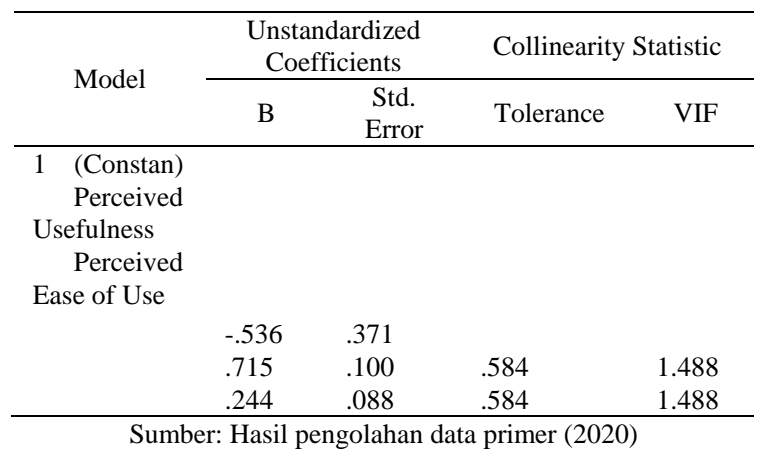

Tabel 12 menunjukkan bahwa nilai tolerance untuk variabel perceived usefulness dan perceived ease of use berturut-turut adalah 0,584 dan 0,584 Karena nilai-nilai ini berada di atas nilai cut-off 0,10 maka dapat disimpulkan bahwa model regresi tidak mengandung problem moltikolinieritas. Demikian juga, halnya jika ditinjau dari nilai VIF dari variabel bebas berturut-turut sebesar 1,488, dan 1,488 yang berada di bawah nilai cut-off sebesar 10,00. Karena nilai VIF berada di bawah 10,0 maka dapat disimpulkan bahwa model regresi tidak mengandung problem moltikolinieritas.

\section{c. Hasil uji Heteroskedastisitas}

Ghozali [14] menyebutkan bahwa uji heterokedasitas bertujuan untuk menguji apakah dalam model regresi terjadi ketidaksamaan variance dari residual satu pengamatan ke pengamatan yang lain. Jika variance dari residual satu pengamatan ke pengamatan lain tetap (atau mendekati sama) maka disebut model berada pada kondisi homoskedastisitas dan jika berbeda disebut heteroskedastisitas. Model regresi yang baik adalah model yang tidak memiliki problem heterokedasitisitas, sehingga variance dari residual satu pengamatan ke pengamatan yang lain mendekati sama [14]. Dalam penelitian ini, digunakan uji Glejser dalam menguji ada tidaknya heteroskedastisitas.

Uji Glejser dilakukan dengan meregresi variabel nilai absout residu (AbsUt) terhadap semua variabel independen dalam model. Pengukuran variabel dikatakan terbebas dari heteroskedastisitas dapat dilihat dari probabilitas signifikansinya, bila tingkat signifikannya berada di atas 5\% maka dapat disimpulkan model regresi tersebut tidak mengandung problem heterokedastisitas. Artinya, variabel-variabel independen tidak memiliki pengaruh nyata terhadap nilai absolut dari residu (AbsUt). Tabel 13 menunjukkan hasil dari pengujian heteroskedastisitas.

TABEL 13 HASIL UJI HETEROSKEDASTISITAS

\begin{tabular}{cccccc}
\hline \multirow{3}{*}{ Model } & \multicolumn{2}{c}{$\begin{array}{c}\text { Unstandardized } \\
\text { Coefficients }\end{array}$} & $\begin{array}{c}\text { Standardized } \\
\text { Coefficients }\end{array}$ & & \multirow{2}{*}{ Sig. } \\
\cline { 2 - 3 } & B & Std. & Beta & & \\
\hline & Error & & & \\
\hline
\end{tabular}


1

(Constan)

Perceived

Usefulness

\begin{tabular}{llllll} 
Perceived & .477 & .250 & & 2.005 & .028 \\
Ease of & -.033 & .072 & -.055 & -.332 & .380 \\
Use & -.022 & .064 & -.050 & -.316 & .385 \\
\hline \multicolumn{5}{c}{ Sumber: Hasil pengolahan data primer (2020) }
\end{tabular}

Tabel 13 menunjukkan bahwa nilai signifikansi $\mathrm{p}$ untuk variabel perceived usefulness dan perceived ease of use berturut-turut adalah 0,380 dan 0,385. Nilai signifikansi tersebut terbukti lebih besar dari 0,05 sehingga dapat disimpulkan bahwa model regresi yang diteliti tidak mengandung problem heteroskedastisitas.

\subsection{Estimasi Model Regresi}

Estimasi model regresi yang dapat dijelaskan dalam bentuk persamaan regresi linier berganda sebagai berikut:

$$
\mathrm{Y}=\mathrm{a}_{1}+\mathrm{b}_{1} \mathrm{X}_{1}+\mathrm{b}_{2} \mathrm{X}_{2}+\mathrm{e}
$$

Keterangan:

$\begin{array}{lll}\mathrm{Y} & : & \text { Attitude toward using } \\ \mathrm{X}_{1} & : & \text { Perceived usefulness } \\ \mathrm{X}_{2} & : & \text { Perceived ease of use } \\ \mathrm{A} & : & \text { Konstanta regresi } \\ \mathrm{b}_{1}, \mathrm{~b}_{2} & : & \text { Koefisien regresi } \\ \mathrm{E} & : & \text { Residu atau error terms }\end{array}$

a. Persamaan Regresi

Persamaan regresi linier berganda pada penelitian ini dapat dihasilkan dengan memasukkan nilai konstanta dan koefisien regresi ke dalam Persamaan. Nilai konstanta dan koefisien regresi dapat dilihat dari hasil keluaran SPSS untuk koefisien persamaan regresi dapat dilihat pada Tabel 14 berikut.

\begin{tabular}{|c|c|c|c|c|c|}
\hline \multirow{2}{*}{ Model } & \multicolumn{2}{|c|}{$\begin{array}{c}\text { Unstandardized } \\
\text { Coefficients }\end{array}$} & \multirow{2}{*}{$\begin{array}{c}\begin{array}{c}\text { Standardized } \\
\text { Coefficients }\end{array} \\
\text { Beta }\end{array}$} & \multirow{2}{*}{1} & \multirow{2}{*}{ Sig. } \\
\hline & B & $\begin{array}{c}\text { Std. } \\
\text { Error }\end{array}$ & & & \\
\hline $\begin{array}{l}1 \\
\text { (Constan) }\end{array}$ & & & & & \\
\hline $\begin{array}{l}\text { Perceived } \\
\text { Usefulness }\end{array}$ & & & & & \\
\hline $\begin{array}{l}\text { Perceived } \\
\text { Ease of } \\
\text { Use }\end{array}$ & $\begin{array}{l}-.586 \\
.785 \\
.225\end{array}$ & $\begin{array}{l}.381 \\
.110 \\
.098\end{array}$ & $\begin{array}{l}.551 \\
.221\end{array}$ & $\begin{array}{l}- \\
1.841 \\
6.627 \\
1.589\end{array}$ & $\begin{array}{l}.112 \\
.000 \\
.011\end{array}$ \\
\hline
\end{tabular}

b. Koefisien Determinasi $\left(\mathrm{R}^{2}\right)$

Ghozali [14] menjelaskan bahwa koefisien determinasi $\left(\mathrm{R}^{2}\right)$ pada intinya mengukur seberapa jauh kemampuan model dalam menerangkan variasi variabel dependen. Nilai $\mathrm{R}^{2}$ berada di antara nol dan satu. Nilai $R^{2}$ yang kecil berarti kemampuan variabel-variabel independen dalam menjelaskan variabel dependen sangat terbatas. Nilai yang mendekati satu berarti variabel-variabel independen memberikan hampir semua informasi yang dibutuhkan untuk memprediksi variasi variabel independen.

Keluaran (output) SPSS untuk nilai $\mathrm{R}^{2}$ menunjukkan nilai sebesar 0,618. Angka ini menunjukkan bahwa 0,618 atau $61,8 \%$ variasi atau perubahan pada variabel dependen Attitude toward Using dapat dijelaskan oleh variabel independen $\mathrm{X}_{1}$ (Perceived Usefulness) dan $\mathrm{X}_{2}$ (Perceived Ease of Use), sedangkan $38,2 \%$ sisanya dipengaruhi oleh variabel lain di luar model regresi yang digunakan.

\section{c. Pengujian Hipotesis}

Hasil pengujian hipotesis didasarkan pada nilai signifikansi $\mathrm{p}$ yang dapat dilihat pada Tabel 15 berikut.

TABEL 15 RANGKUMAN HASIL PENGUJIAN HIPOTESIS

\begin{tabular}{llll}
\multicolumn{1}{c}{ Variabel } & thitung & Signifikansi p & Pengaruh \\
\hline $\begin{array}{l}\text { Perceived } \\
\text { Usefulness }\left(\mathrm{X}_{1}\right)\end{array}$ & 4,114 & 0,000 & Signifikan \\
\hline $\begin{array}{l}\text { Perceived Ease } \\
\text { of Use }\left(\mathrm{X}_{2}\right)\end{array}$ & 2,898 & 0,011 & Signifikan \\
\hline
\end{tabular}

Variabel dependen: Y (Attitude toward using)

Nilai statistik F hitung $=23,556($ signifikansi $\mathrm{p}=0,000)$

Sumber: Hasil pengolahan data primer (2020)

Kriteria pengujian hipotesis yang digunakan adalah jika nilai signifikansi sp untuk nilai t statistik $>$ 0,05, maka hipotesis ditolak. Sementara itu, pengujian pengaruh simultan kedua variabel $\mathrm{X}_{1}$ dan $\mathrm{X}_{2}$ terhadap $\mathrm{Y}$ (Attitude toward using) dilakukan dengan melihat nilai signifikansi $\mathrm{p}$ dari nilai $\mathrm{F}$ statistik, yaitu jika nilai $p>0,05$ maka hipotesis ditolak. Hasil pengujian hipotesis disajikan sebagai berikut:

H1 : Attitude toward Using Sistem Perpustakaan UNISS Kendal dipengaruhi secara signifikan oleh Perceived Usefulness diterima karena t hitung $=4,114$ dengan signifikansi $\mathrm{p}=0,000(<0,05)$.

$\mathrm{H} 2$ : Attitude toward Using Sistem Perpustakaan UNISS Kendal dipengaruhi secara signifikan oleh Perceived Ease of Use diterima karena t hitung $=2,898$ dengan signifikansi $\mathrm{p}=0,010(<0,05)$ 
H3 : Attitude toward Using Sistem Perpustakaan UNISS Kendal dipengaruhi secara signifikan oleh Perceived Usefulness dan Perceived Ease of Use diterima karena nilai statistik $\mathrm{F}$ hitung $=23,556$ dengan signifikansi $\mathrm{p}=0,000(<0,05)$.

\section{Kesimpulan}

Kesimpulan dari penelitian yang telah dilakukan tentang Penerapan Technology Acceptance Model pada E-Library UNISS Kendal Berbasis Web adalah

1. Perceived usefulness, perceived ease of use, dan attitude toward using masuk dalam kategori "tinggi." Ini menunjukkan bahwa Sistem Perpustakaan UNISS Kendal dinilai baik oleh para pengguna sistem.

2. Attitude toward Using Sistem Perpustakaan UNISS Kendal mendapatkan pengaruh secara signifikan oleh Perceived Usefulness, jadi sikap terhadap penggunaan akan mengalami peningkatan ketika kegunaan yang dirasakan mengalami peningkatan.

3. Attitude toward Using Sistem Perpustakaan UNISS Kendal mendapatkan pengaruh secara signifikan oleh Perceived Ease of Use, jadi sikap terhadap penggunaan akan mengalami peningkatan ketika sistem dirasakan semakin mudah oleh pengguna.

4. Attitude toward Using Sistem Perpustakaan UNISS Kendal mendapatkan pengaruh secara signifikan oleh Perceived Usefulness dan Perceived Ease of Use. Jadi Attitude toward Using dipengaruhi secara simultan terhadap oleh variabel perceived usefulness dan perceived ease of use secara bersama-sama.

\section{Daftar Pustaka}

[1] Davis, F. D., Perceived Usefulness, Perceived Ease of Use, and User Acceptance of Information Technology, MIS Quaterly, No. 3, Vol. 13, Hal. 319340, 1989.

[2] Järvinen, J., Consumer Acceptance and Use of Instagram, Hawaii International Conference on System Sciences (HICSS), Koloa, USA, January 5-8, 2016.

[3] Megawati, Analisis Perbandingan Metode Tam dan Utaut Dalam Mengevaluasi Penerimaan Pengguna Sistem Informasi Manajemen Rumah Sakit (SIMRS), SNTIKI 9, Pekanbaru, Hal. 299-307, 2017.

[4] Wingdes, I., Penerimaan Tekonologi Web Check-In pada Pengguna Transportasi Udara di Kalimantan Barat, Creative Information Technology Journal (CITEC Journal), No. 1, Vol. 3, Hal. 37-49, 2016.
[5] Sugiarto, S., Lianto, R., Analisis Penerapan Sistem Akuntansi Persediaan Menggunakan Technology Acceptance Model (TAM) pada Distrik Navigasi Kelas III Pontianak, STMIK Pontianak Online Journal (Jurnal Ilmiah SISFOTENIKA), No. 2, Vol. 1, Hal. 80-94, 2011.

[6] Rozanda, E., Perbandingan Metode Hot Fit dan Tam dalam Mengevaluasi Penerapan Sistem Informasi, Seminar Nasional Teknologi Informasi, SNTIKI 9, Pekanbaru, Hal. 327-336, 2017.

[7] Mulik, S., Yajnik, N., Godse, M., Determinants of Acceptance of Massive Open Online Courses, IEEE International Conference on Technology for Education, Mumbai, India, December 2-4, 2016.

[8] Hasibuan, Zainal A., Metodologi Penelitian Pada Bidang Ilmu Komputer dan Teknologi Informasi, Fakultas ILKOM UI, Jakarta, 2007.

[9] Rasyad, Metode Statistik Deskriptif, Grahasindo, Jakarta, 2003.

[10] Riduwan, Metode Penelitian Untuk Tesis, Alfabeta, Bandung, 2007.

[11] Triton, P. B., SPSS 13.0 Terapan: Riset Statistik Parametrik, Penerbit Andi Offset, Yogyakarta, 2006.

[12] Arikunto, S., Prosedur Penelitian: suatu Pendekatan Praktik, Ed. rev., cet. 14, Rineka Cipta, Jakarta, 2010.

[13] Azwar, S., Penyusunan Skala Psikologi, Penerbit Pustaka Pelajar, Yogyakarta, 2003.

[14] Ghozali, Imam, Model Persamaan Struktural Konsep dan Aplikasi dengan Program Amos 21.0, Badan Penerbit Universitas Diponegoro, Semarang, 2013.

[15] S. Kosinov, "Evaluation of N-Grams Conflation Approach In Text-Based Information Retrieval," Proceedings. Eighth Symposium on String Processing and Information Retrieval, 2001. 